\title{
RAZGLEDI
}

\section{SLEDI RURALNE DEDIŠČINE V URBANI POKRAJINI: OBZIDANI VRTOVI NA PRIMERU BOVŠKEGA}

\author{
AVTORJA \\ dr. Blaž Komac \\ Znanstvenoraziskovalni center Slovenske akademije znanosti in umetnosti, Geografski inštitut Antona Melika, \\ Gosposka ulica 13, SI - 1000 Ljubljana, Slovenija; blaz.komac@zrc-sazu.si
}

dr. Domen Kušar

Univerza v Ljubljani, Fakulteta za arhitekturo, Zoisova cesta 12, SI - 1000 Ljubljana, Slovenija

domen.kusar@fa.uni-lj.si

DOI: $10.3986 / G V 89104$

UDK: 911.37:712.35(497.473Bovec)

COBISS: 1.01

\section{IZVLEČEK}

\section{Sledi ruralne dediščine v urbani pokrajini: obzidani vrtovi na primeru Bovškega}

Članek obravnava s kamnitimi zidovi obdane vrtove na Bovškem. Vrtovi so nastali na robu naselja, kjer urbana struktura prehaja $v$ podeželsko. Zanje so posebej značilni visoki kamniti zidovi, ki so značilnost sredozemskih kulturnih območij. Nastanek zidov okrog vrtov je povezan s čiščenjem kmetijskih zemljišč zaradi lažje obdelave, trajnejšo razmejitvijo parcel ter preprečevanjem prehoda živini in divjadi. To je pogosto spregledana kulturna dediščina, saj sedanja raba prostora in prostorski načrti občine Bovec kažeta majhno zavedanje o pomenu zidov kot kakovostnih elementov prostora. Namen članka je predstaviti tipe, stanje in namen vrtnih zidov ter opozoriti na dejstvo, da takšni prostorski elementi dvigajo kakovost bivalnega okolja in predstavljajo razvojni, zlasti turistični potencial.

\section{KLJUČNE BESEDE}

geografija, arhitektura, vrtni zid, suhi zid, vrt, kulturna dediščina, Bovec

\begin{abstract}
Traces of rural heritage in urban landscapes: walled yards in the Bovec area

This article explores the walled yards in the Bovec area. These yards were created on the edges of the town, where the urban structure transitions into a rural one. They are characterized by high stone walls typical of the Mediterranean cultural environments. Their origins are connected with clearing agricultural land to semi-permanently delimit parcels, and to keep livestock and wildlife out. This is a frequently overlooked element of cultural heritage because the current spatial use and the spatial plans of the Municipality of Bovec show little consideration for the importance of walls as high-quality spatial elements. The article presents the types, current state, and purpose of walled yards, and draws attention to the fact that such spatial elements increase the quality of the living environment and provide development potential, especially in tourism.
\end{abstract}

KEY WORDS

geography, architecture, wall, dry-stone wall, garden, cultural heritage, Bovec

Uredništvo je prispevek prejelo 21. junija 2017. 


\section{Uvod}

V članku obravnavamo z zidovi obdane vrtove s poudarkom na njihovi funkcionalno in estetsko najpomembnejši sestavini, kamnitih vrtnih zidovih. Obmestni vrtovi, ki jih obdajajo kamniti zidovi, so pomembna podeželska prvina urbane pokrajine. Kamniti zidovi so posebej značilni za sredozemske pokrajine, kjer zaznamujejo tako urbana kot podeželska območja. V članku predstavljamo zanimiv primer njihove rabe na stiku urbane in podeželske rabe. Procesi spreminjanja pokrajine so prav na tem stiku najbolj intenzivni (Razpotnik Visković in Komac 2018), zato je zanimivo opažanje, da so obravnavane pokrajinske strukture stabilne.

V članku bomo najprej predstavili splošne značilnosti zidov, jih nato obravnavali kot nujen sestavni del obmestnih vrtov in predstavili značilne tipe, nazadnje pa še njihov pomen v sodobnosti za stično urbano-podeželsko območje. Nanje bomo navezali spremembo nekaterih kamnitih zidov v različne vrste ograj, oziroma postavitvijo le-teh, ki smo ji priča od konca prve svetovne vojne dalje.

Kamniti zidovi spadajo med obsežne posledice človeške dejavnosti, običajno povezne s kmetijstvom in ustrezno kamninsko podlago. Gre za staro obliko zbiranja in »odlaganja « odvečnega kamenja, vzpostavitev mej med parcelami, izboljšanje mikropodnebnih razmer ter razmer za kmetijstvo. Poznamo dva najpogostejša tipa zidov: oporni zid in samostoječi zid.

Oporni zidovi preprečujejo sesedanje in izpiranje zemlje z višje ležečih predelov na nižje ležeče, zato so jih uporabljali na nagnjenem površju pri oblikovanju teras (Gams 2003; Ažman Momirski in Kladnik 2009; Kladnik s sodelavci 2016). Oporni zidovi so bili zgrajeni po principu suhega zidu iz ustreznega krajevnega gradbenega materiala (tip A1 na sliki 1). V novejšem času se namesto suhega zidu uveljavlja zidan zid iz kamenja in redkeje opeke oziroma vliti armiranobetonski zid (tip A2 na sliki 1).

Eno- ali dvoredni samostoječ zid pa je značilen predvsem za ravnine. Ponekod je gradnja takšnih zidov močno spremenila pokrajino. Kamniti zidovi so pogosti na krasu, zato jih imenujemo tudi kraški zidovi. Zgrajeni so iz skrbno zloženega kamenja, za kar se je uveljavil izraz suhi zid oziroma suhozid ali tudi suhizid (medmrežje 1). Najpogostejši so na Krasu in na sredozemski strani Dinarskega krasa, ob Soči segajo do Bovškega, so tudi na Hrušici, Nanosu in Banjšicah. Manj jih je na Idrijskem in Notranjskem ter v Posavskem hribovju (Gams 2003). Skrbna izdelava in ustrezen lokalni material omogočata obstanek zidovom še danes. Na Divaškem krasu je povprečna prostorska gostota

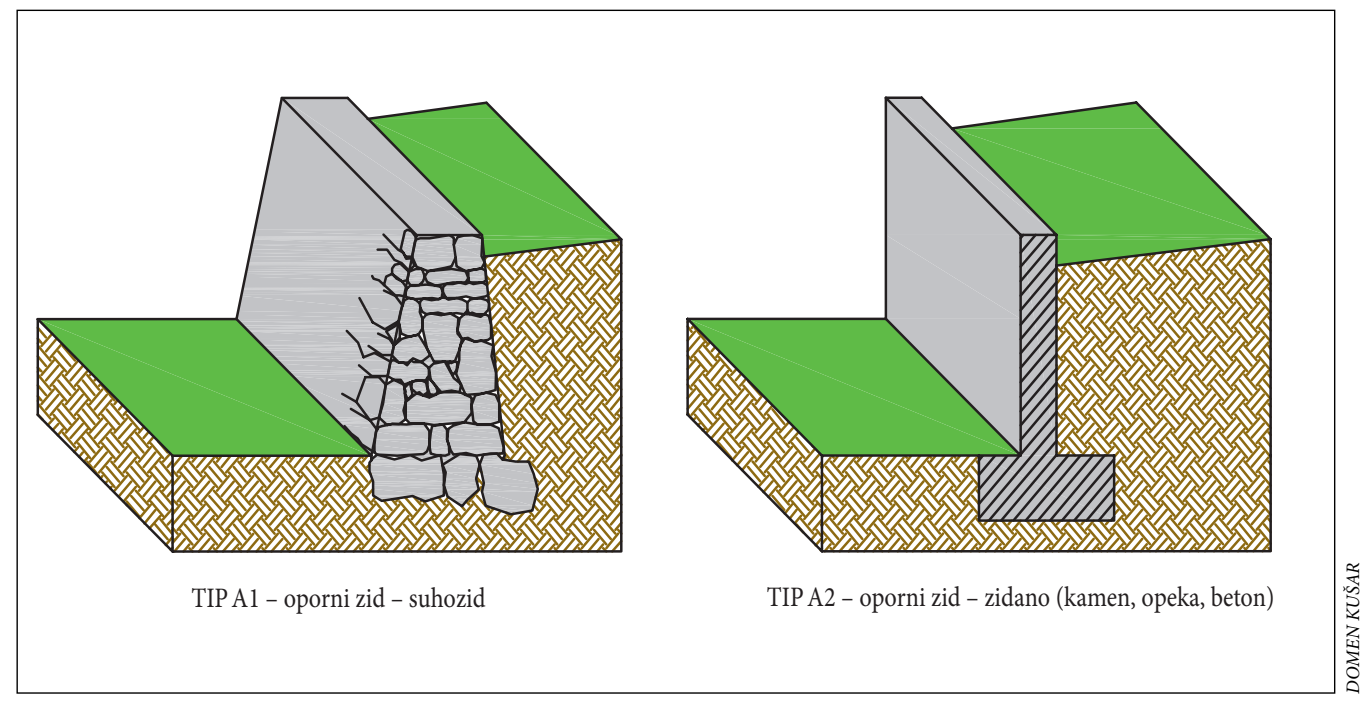

Slika 1: Tipa opornih zidov teras. 
takšnih suhih zidov $100 \mathrm{~m} /$ ha, blizu Lokev pa je v ogradi nekdanjega vrta toliko kamna, da ga pride na $1 \mathrm{~m}^{2}$ vrta $278 \mathrm{~kg}$, ponekod v Dalmaciji pa tudi do dve toni (približno 1,6 $\mathrm{m}^{3}$ ) na kvadratni meter (Gams 2003).

$\mathrm{Na}$ Bovškem so bili v preteklosti značilni oporni suhi zidovi nasutih teras, ki jim rečejo kašta (Hrvatin 1988). Mír je samostoječ zid, prav tako grajen po principu suhe gradnje, ki pogosto označuje lastniško mejo, različni rastni kulturi (Kajzelj 1997). Dva takšna zidova obdajata pot, obdajajo pa tudi vrtove. Zato so míri značilni za okolico naselij. Na Valvasorjevi podobi Štanjela so pred vhodom v naselje vidni obcestni zidovi in ograjen nasad drevja (Panjek 2015). Škotski matematik W. A. Cadell, ki je leta 1817 pripotoval na Kras, je opazil, da je v Lipici blizu ceste »... na z drevesi poraščenem zemljišču, ograjenem $z$ zidom ...«, kobilarna za vzrejo konj (Shaw 2000, 110-111).

Za obrobje naselja Bovec so značilni mogočni zidovi, ki obdajajo domačije in njihove vrtove ter »manjkajo malokje« in so, kot ugotavlja Melik $(1962,338)$ očitno »dediščina iz velike davnine (slika 2).

Zidovi okoli vrtov v Bovcu so nastali na robu starih delov naselja, kot sta središče in delno Dvor, manj pa jih je $\mathrm{v}$ gosteje pozidanem osredju in okoli novejših delov naselja. Značilni so tudi za večje kmetije v okoliških vaseh, kot sta Čezsoča in Žaga ter za razložena naselja okrog Bovca, kot sta Ravni Laz in Zavrzelno na pobočjih Rombona (Hrvatin 1988), kjer so bile prestaje. Melik $(1962,359)$ ugotavlja, "...da so ti zidovi samo varianta starodavnega običaja, da so določene prostore zavarovali pred nekontroliranim prehajanjem živine ... «, kar podpira tudi Moritsch (1969). Tovrstno zavarovanje je bilo potrebno, saj so živino na Bovškem pozimi pogosto gnali od ene prestaje k drugi, kjer so jo krmili s senom. Tak način hranjenja živine se razlikuje od tistega na primer v Bohinju, kjer je bila živina čez zimo $\mathrm{v}$ vaseh po hlevih, seno pa so $\mathrm{z}$ višje ležečih senikov pripeljali v dolino s sanmi (Melik 1950). V Bovcu je ohranjeno ustno izročilo, da so tako visoke zidove gradili tudi za varovanje pred volkovi (Pavlin 2017); izvor informacije lahko iščemo najpozneje na koncu 19. stoletja. Pred volkovi so živino, ki se je pasla na pobočju Rombona, ponoči varovali tudi tako, da so kopali jame, v katerih so kurili ogenj (takšna

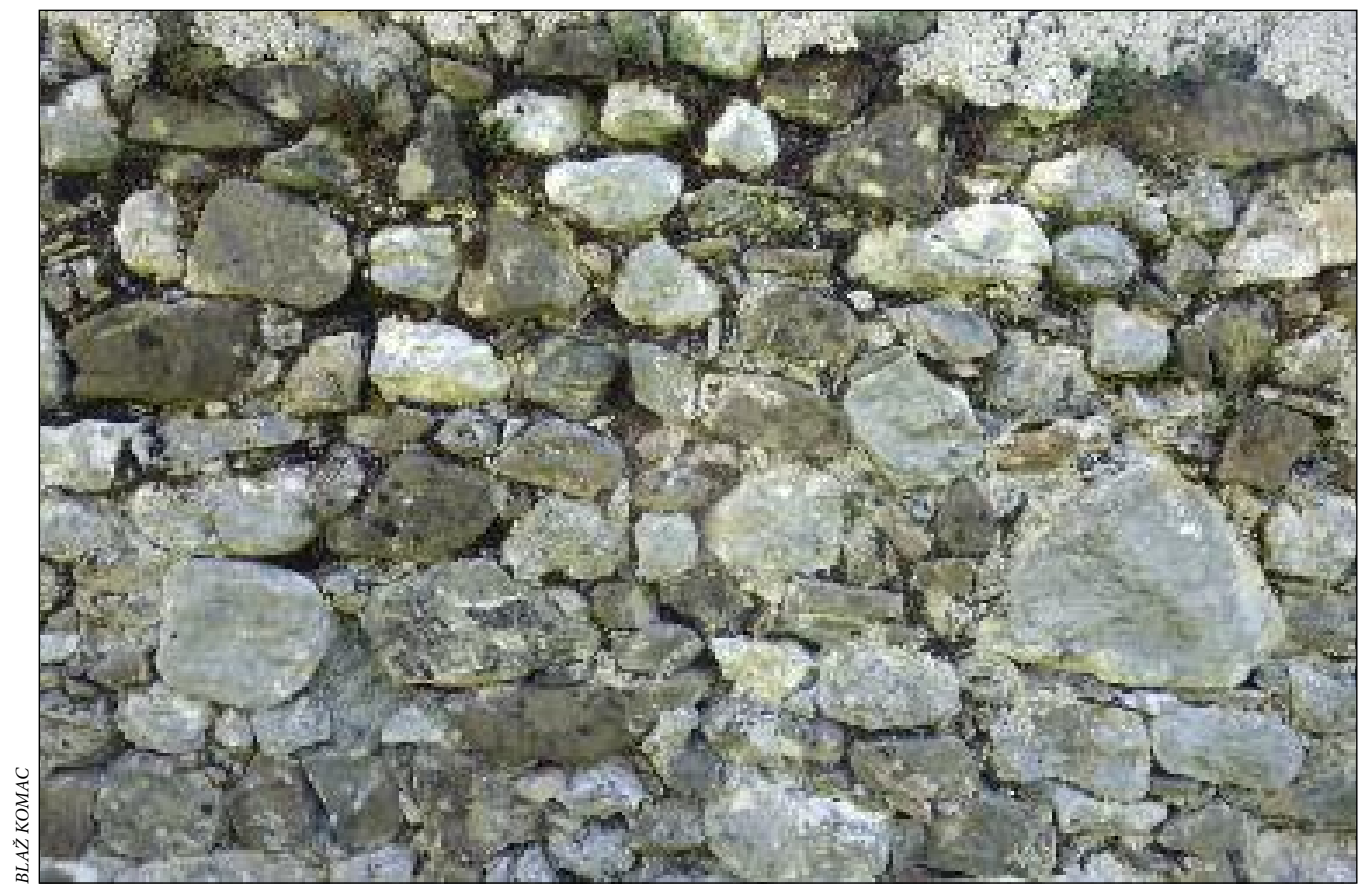

Slika 2: Kamnita struktura enega najstarejših zidov v Bovcu. 
jama je bila pred desetletji še vidna nad Bovcem; Hosner 2017.) ali pa so imele globoke jame funkcijo pasti (od tod ledinsko ime Wəčja ali Volčja jama nad Čezsočo).

Nasprotno pa Pagnini (1966) poudarja zidove kot način označevanja meje zasebne lastnine. To posebej velja za razmejitev zasebnih vrtov, kot jih obravnavamo v tem članku, in skupnimi zemljišči neobdelanega sveta, potmi ali pašniki, na katerih je pravico do paše uživala širša vaška skupnost. Tudi na Krasu imajo zidovi, poleg funkcije varovanja redkih njiv pred sunki burje, funkcijo označevanja ter razmejevanja posesti in lastnine. Proces ograjevanja posesti je na Krasu dokumentirano potekal $\mathrm{v}$ dveh fazah: $\mathrm{v} 18$. stoletju so razdeljevali srenjsko zemljo med člane skupnosti in nato gradili mejne zidove med novimi parcelami sredi bivše gmajne, drugič pa so parcele ograjevali po zemljiški odvezi leta 1848 (Panjek 2015). Tudi v angleški pokrajini Yorkshire so največ suhih zidov zgradili na začetku novega veka, ko so fevdalno zemljo razdelili med kmete. Genetsko so zidovi stranski proizvod melioracije zemljišč, zato so jih pri nas največ zgradili v obdobjih razširjanja njiv in travnikov (Gams 2003).

Z raziskovanjem takšnih zidov se je ukvarjalo že veliko avtorjev, bistveno manj raziskani pa so zidovi znotraj naselij, kjer je prostor predragocen za večje nepozidane parcele. Na robu naselij ali pa $\mathrm{v}$ naseljih, ki so nastala kot predmestja in so bila brez obzidja, pa je bila večja možnost posedovanja večjih parcel. Hiše niso bile strnjene ena ob drugi, pač pa so imele okoli tudi proste površine, ki se jih lahko obzida. Eden od razlogov za to so bile tudi zahteve varstva pred požarom, saj se je v strnjenih naseljih požar lažje širil s strehe na streho (Kušar 2003). »Postava sa volo ogna na kmetih« (1795) zahteva med hišami razmak vsaj enega sežnja ali klaftre, kar je enako 1,896 m. Med hišami priporoča sajenje dreves z veliko listja (oreh), ki naj bi preprečevala širjenje požara. Prosta zemljišča med stavbami so bila namenjena različni rabi (obrtna, skladiščna, rekreativna, estetska, pridelovalna), lastniki pa so jih iz različnih vzrokov ogradili. $Z$ razvojem naselij so se spreminjale tudi te površine, a so se površine in zidovi kljub temu marsikje ohranili do danes.

Za razvojem gradbene tehnike in dostopnostjo novih materialov so se nekateri prvotni suhi zidovi začeli umikati zidanim. Slednje so kasneje začele izpodrivati različne vrste ograj, ki so še vedno ohranjale vlogo »zidu« kot elementa razmejitve, vizualne ovire za zagotavljanje zasebnosti in kot način preprečevanja dostopa na ograjena zemljišča.

V članku obravnavamo zidove kot zanimiv element pokrajine, ki odsevajo povezanost podeželske in (sub)urbane pokrajine. Zaradi svoje starosti so eno od vidnih znamenj družbeno-gospodarskega prehoda. Raziskavo smo naredili, ker menimo, da gre za pomembno prvino tako zanimive stične pokrajine, kot je urbano-podeželski kontinuum.

Bovec je primer kraja z razmeroma dobro ohranjenimi zidovi, ki so sestavni del urbane celote znotraj in na robu naselja ter kakovosten element urbano-podeželskega kontinuuma oziroma urbano pohištvo. Raziskali smo pomen teh zidov, njihov nastanek, uporabo in spremembo v druge oblike »zidov«. Zidovi so namreč neposredno povezani tudi z zelenimi površinami, ki jih omejujejo, te pa so zelo pomembne za kakovost življenja v naseljih (Tiran 2016).

Bovški zidovi so hkrati sestavni del območja obzidanih vrtov in dvorišč ter tvorijo kulturno dediščino $\mathrm{z}$ velikim potencialom za nadaljnji razvoj. Prvotna funkcija pridelave zelenjave, ki je bila nekdaj življenjskega pomena za uporabnike, danes pomeni vse bolj priljubljeno obliko vrtičkarstva oziroma lahko omogoča dodatno turistično ponudbo $v$ obliki pridelave butične ekološke zelenjave za goste ali pa zagotavlja zaseben zelen prostor - park v urbanem sredičču. Zato bi bilo nujno treba doseči večje zavedanje o bogastvu pri lastnikih ter vrtove in zidove skupaj z ohranjeno naselbinsko strukturo ustrezno zaščititi. V raziskavi smo preverili trenutno stanje zaščite zidov in vrtov v Bovcu s strani države in občine. Način zaščite smo nato primerjali z zaščito ruralne dediščine $\mathrm{v}$ urbanem okolju Ljubljane in sicer na primeru Krakovskih vrtov. Ti vrtovi sicer niso primerljivo ograjeni z zidovi in ograjami kot v Bovcu, vendar tvorijo skupaj z naselbinsko strukturo neločljivo povezano zaključeno ruralno celoto $\mathrm{v}$ urbanem okolju. 


\section{Metode}

Raziskava se je osredotočila na Bovec, kjer smo s pomočjo primerjav različnih načrtov, kot so franciscejski kataster, sodobni katastrski načrt, digitalni ortofotografski posnetek, ogledov na terenu in $\mathrm{z}$ uporabo sodobne tehnologije ugotavljali osnovne lastnosti zidov ter razmerje med zidovi in urbanizirano celoto. Tipologijo zidov smo izdelali na podlagi razvrstitve zidov v slovenski gradbeni zakonodaji in terenskem ogledu stanja. Na temelju sinteze pridobljenih podatkov smo ugotovili prevladujoč tip zidov, njihov pomen $\mathrm{v}$ prostoru, likovno sporočilnost in tendence razvoja.

Da bi ugotovili stopnjo prepoznavnosti in varovanja teh prostorskih kvalitet $\mathrm{v}$ uradnih dokumentih, smo preverili trenutno veljavni Občinski prostorski načrt Občine Bovec (2013) in obravnavali varovanje tovrstnega dela urbane celote.

\section{Vrtni zidovi}

$\mathrm{Na}$ Bovškem so, podobno kot drugje na krasu, kmetje spravljali v kupe in zlagali v mejne ter podporne zidove kamenje, ki je zaradi kmetijske erozije predvsem zaradi paše in oranja nenehno sililo na površje. Suhi zidovi obdajajo parcele in poti; med parcelami so zrasli značilni suhi zidovi, groblje, gomile, kašte in míri ter s kamenjem tlakovane in obdane poti. To pokrajino uvršča v sredozemski kulturni prostor. Za kulturno pokrajino krasa so značilne prvine, s katerimi so omogočili in varovali svojo kmetijsko dejavnost, kot so delane vrtače (Gams 1991), kulturne terase (Kladnik s sodelavci 2016) in kamniti zidovi (Panjek 2015). Čeprav so tovrstni elementi posebej značilni za kras, pa niso izključno značilnost kraških pokrajin (Lago 1994; Nicod 1987). Na katastrski mapi Lokev (na Krasu) iz preteklega stoletja je vrisanih okrog sto okroglastih ograd, ki so varovale njivice pred živalmi (Gams 1987).

Suhi zidovi, značilni za kraška območja, so postavljeni na temelj, ki zagotavlja zidu stabilnost. Temelj sestavljajo večji kamni, položeni na teren, ki je bil očiščen zemlje in korenin. Na temelj so postavljeni kamni, ki se vodoravno prilegajo nalegani strani spodnjih ter tudi v vodoravni smeri sosednjim. Kamni morajo biti ustrezno izbrani, saj v vidnem licu zidov ni izrazitih izboklin ali vboklin. Suhi zid je običajno zgrajen kot dvojni: na temelj sta vzporedno položeni dve vrsti kamnov, med katerima je prazen prostor ali rega. Ta je zapolnjena $\mathrm{z}$ manjšimi kamni ter prečniki, ki povezujejo vrsti in dajejo zidu oporo (Juvanec 2005). Uporaba kamna pri gradnji je v Posočju znana od prazgodovine dalje (Deu 2014). Ker je zid suh, lahko voda ob nalivih prosto odteka in ne izpira materiala iz zidu. Poškodbe zidov so redke in največkrat posledica naravnih dejavnikov, kot so zmrzal, potres ali plazenje. Zato tak zid potrebuje le občasna manjša vzdrževalna dela, kot so ravnanje kamnov, zapolnitev reg in podobno (Zupančič in Vinazza 2015).

Posebna oblika kamnitih zidov so vrtni zidovi, ki obdajajo vrtove in dvorišča ter jih lahko vidimo na obrobju naselja Bovec. Bovški vrtni zidovi so mogočni in visoki. Njihova višina ponekod presega dva metra, kar je več od višine odraslega človeka. Debeli so več kot pol metra. Velikost zidov je nekoliko povezana $\mathrm{z}$ velikostjo vrtov, ki jih obdajajo: večji kot je vrt, višji in masivnejši so zidovi. Zidovi so povečini zidani in povezani z malto (Čok 2014).

Zidovi so skrbneje izdelani v Bovcu in bližje naselja, bolj oddaljeni pa so nižji. Panjek (2015) ugotavlja, da so tudi na Krasu zidovi v bližini naselij višji in bolj pravilnih oblik. Zidani zidovi, ki obdajajo poti (slika 3) in vrtove $\mathrm{v}$ naseljih in tudi zunaj njih, so znak prevlade živinoreje, ki je bila v preteklosti poglavitna gospodarska panoga na tem območju. Za Bovec je bilo značilno, da je »... vsa struktura mestnega prebivalstva [je] takšna, da se takoj vidi, da bivajo tu skupaj kmetje in meščani ... «(Melik 1962, 346), prevladujejo pa hiše z agrarno zasnovo.

Lega Bovca na vznožju Rombona je posledica stika flišnih kamnin $\mathrm{z}$ apnencem, nanosov glinastih sedimentov in več manjših izvirov, ki ne povzročajo takšnih težav kot hudourniški Soča in Koritnica, ob kateri je sicer v Vodencah že v 12. stoletju izpričan mlin (Komac 2001; Ciglič s sodelavci 2012). Pod Bovcem je prodna ravnica Bovške terase, ki je prav tako olajšala obdelavo, Rombon pa je naselju dajal 
Blaž Komac, Domen Kušar $\quad$ Sledi ruralne dediščine v urbani pokrajini: obzidani vrtovi na primeru ...

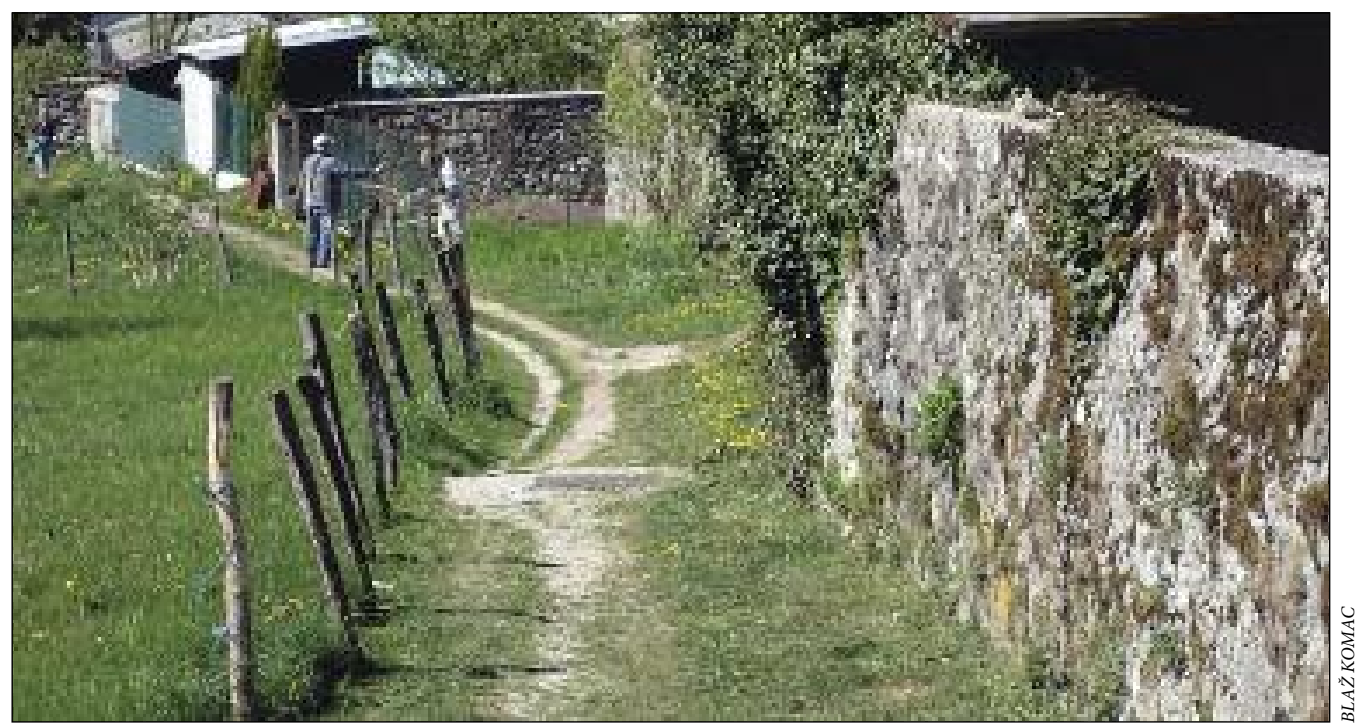

Slika 3: Vzdolž zidov na južnem delu Bovca teče po zunanji strani od vzhoda proti zahodu pešpot.

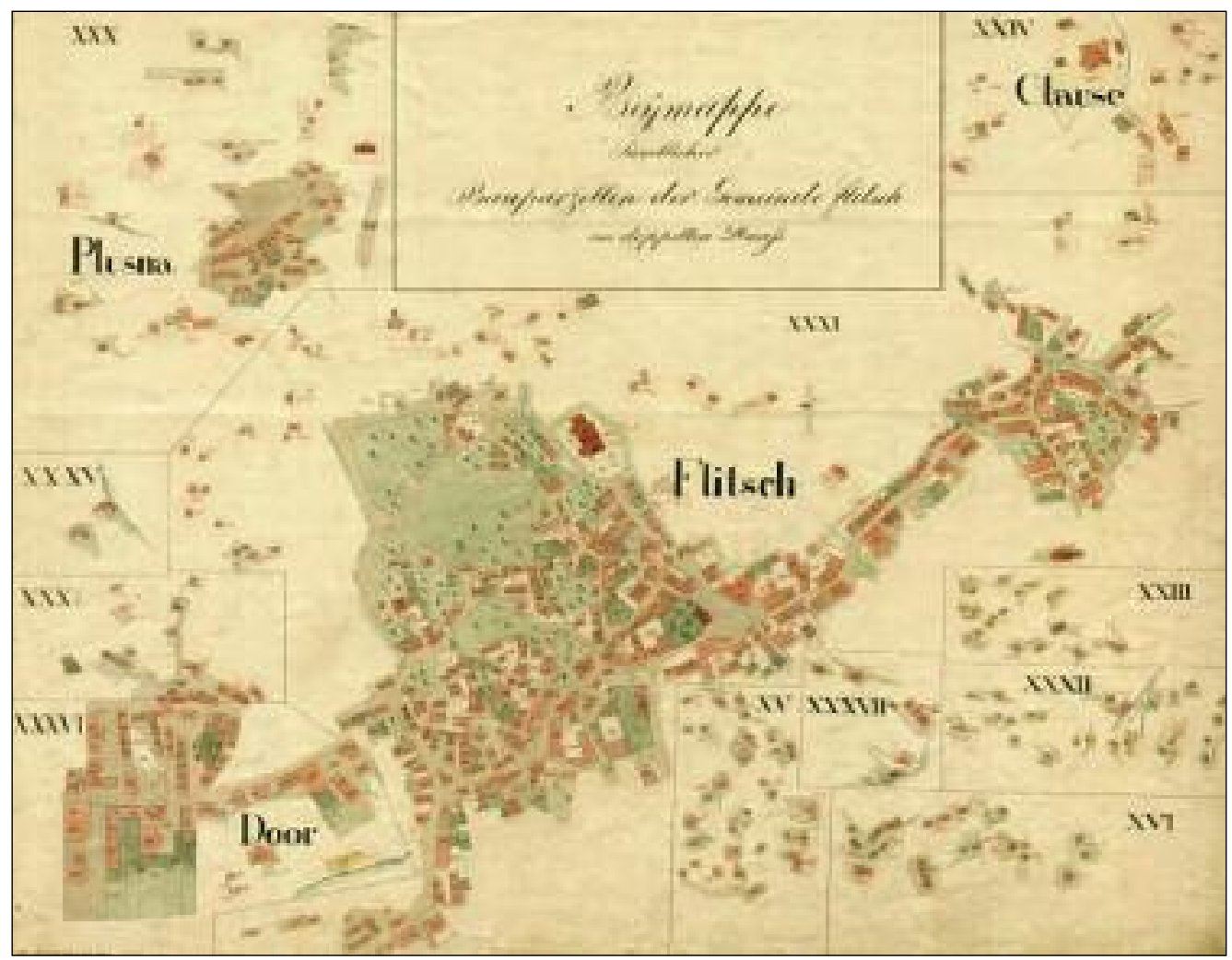

Slika 4: Franciscejski kataster iz obdobja 1811-1813. 
zavetje pred severnikom. Lega vrtnih zidov na robu Bovca je povezana tudi z njegovo lego ob zgodovinsko pomembni poti (Klavora 2003). Stavbe na severnem in predvsem južnem robu naselja obdajajo obzidani vrtovi, zunaj njih pa naselje na severu in jugu obdajata prometnici, na vzhodu in zahodu pa danes delno prekrita potočka. Glavna prometnica se pred Bovcem razcepi na dva dela, ki oklepata središče naselja, in povezujeta nekdanjo samostojno naselje Dvor, omenjeno že leta 1256 , s središčem naselja (primerjaj Franciscejski kataster na sliki 4).

Zidovi v Bovcu so zgrajeni iz lokalnega kamna. Za gradnjo zidov so uporabili ploščate bloke iz peščenjaka iz flišnih kamnin z vznožja Rombona in apnenčaste prodnike z Bovške terase. Po besedah domačina (Kravanja 2017) so po prvi svetovni vojni lomljen kamen v Bovec spuščali z žičnico s pobočij Rombona. Iz enakega gradbenega materiala so zgrajene tradicionalne bovške hiše. Ker zidovi obdajajo vrtove, vodijo vanje široka in visoka vrata, ki pa so po videzu preprosta (slika 6). Nad vrati je praviloma ozka strešica, ki je poleg vrat edini okras zidov. Vrata so tudi edina odprtina v zidovih, ki nimajo lin ali stranskih vrat.

Podoben primer najdemo v Koprivštici v Bolgariji. Kraj je doživel zlato dobo v času bolgarskega narodnega prebujenja. Bogate hiše iz tega obdobja so zavarovane kot kulturni spomeniki. Urbano zasnovo naselja določajo parcele, obkrožene z zidom, znotraj katerih so vrt, park in hiša. Zidovi so zidani, trdnost jim dajejo vodoravne vzdolžne in prečne lesene vezi, pred dežjem pa jih varuje streha. Vrata na dvorišče oziroma $\mathrm{v}$ hišo so edina odprtina $\mathrm{v}$ zidovih. Razlogi za tak način gradnje so bili v tem primeru varnostni, saj je bil kraj večkrat prizorišče uporov proti (otomanski) oblasti (Gheorgiev in Shipeva 1972).

Zidovi na Bovškem propadajo zaradi starosti, zanemarjanja in poškodb v prvi svetovni vojni ter ob potresih v letih 1976, 1998 in 2004, zato jih je treba stalno obnavljati in vzdrževati. To odseva tudi v današnji tipologiji, saj je malo zidov, ki so grajeni kot suhi zid. V strukturi in izgledu zidov se zrcali tudi napredek na področju gradbene tehnike in večje dostopnosti različnih gradiv v zadnjih desetletjih,

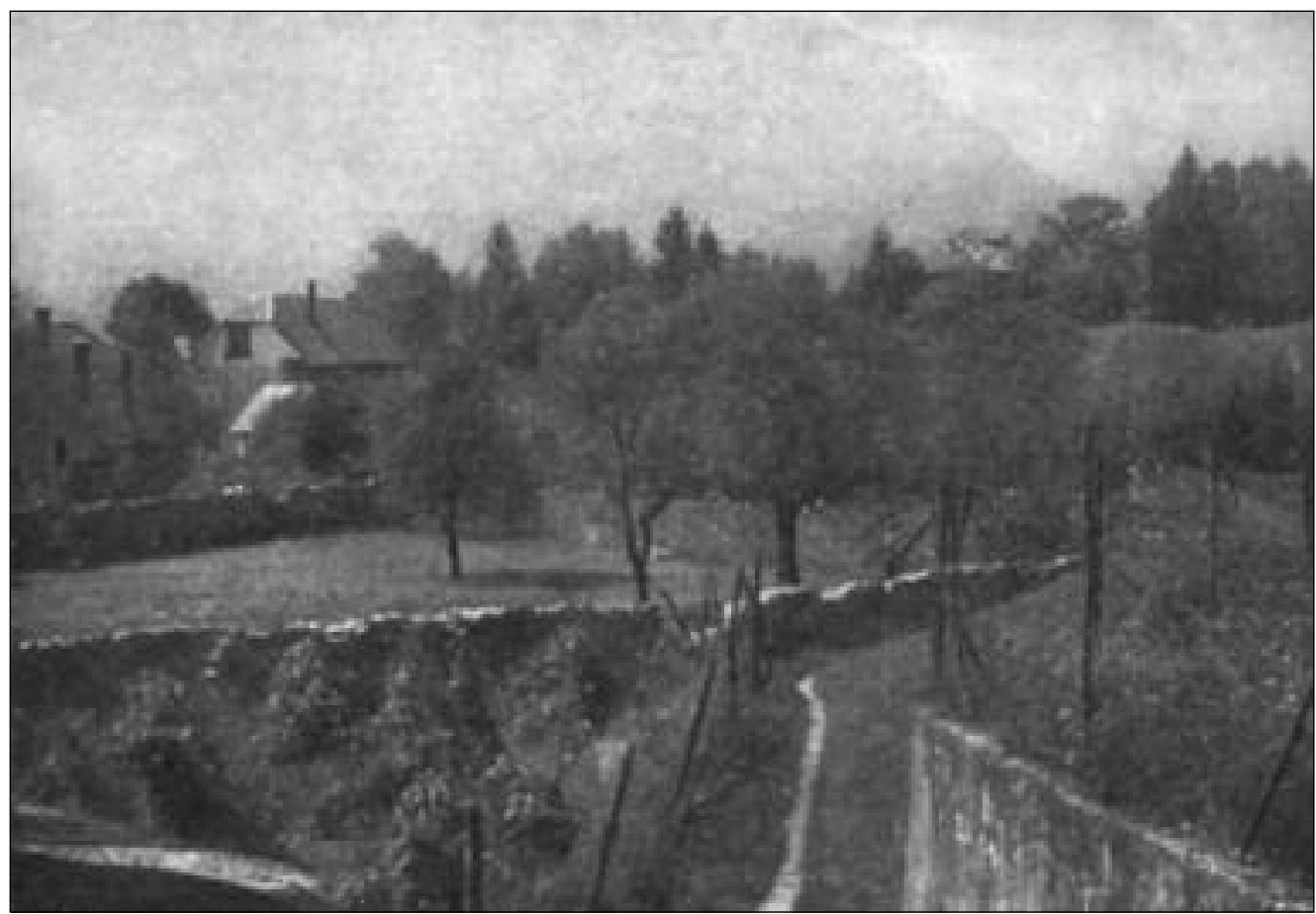

Slika 5: Vrt na robu središča Bovca, na katerem danes stoji zdravstveni dom, obdaja visok vrtni zid (Melik 1962, 358). 
Blaž Komac, Domen Kušar $\quad$ Sledi ruralne dediščine v urbani pokrajini: obzidani vrtovi na primeru ...

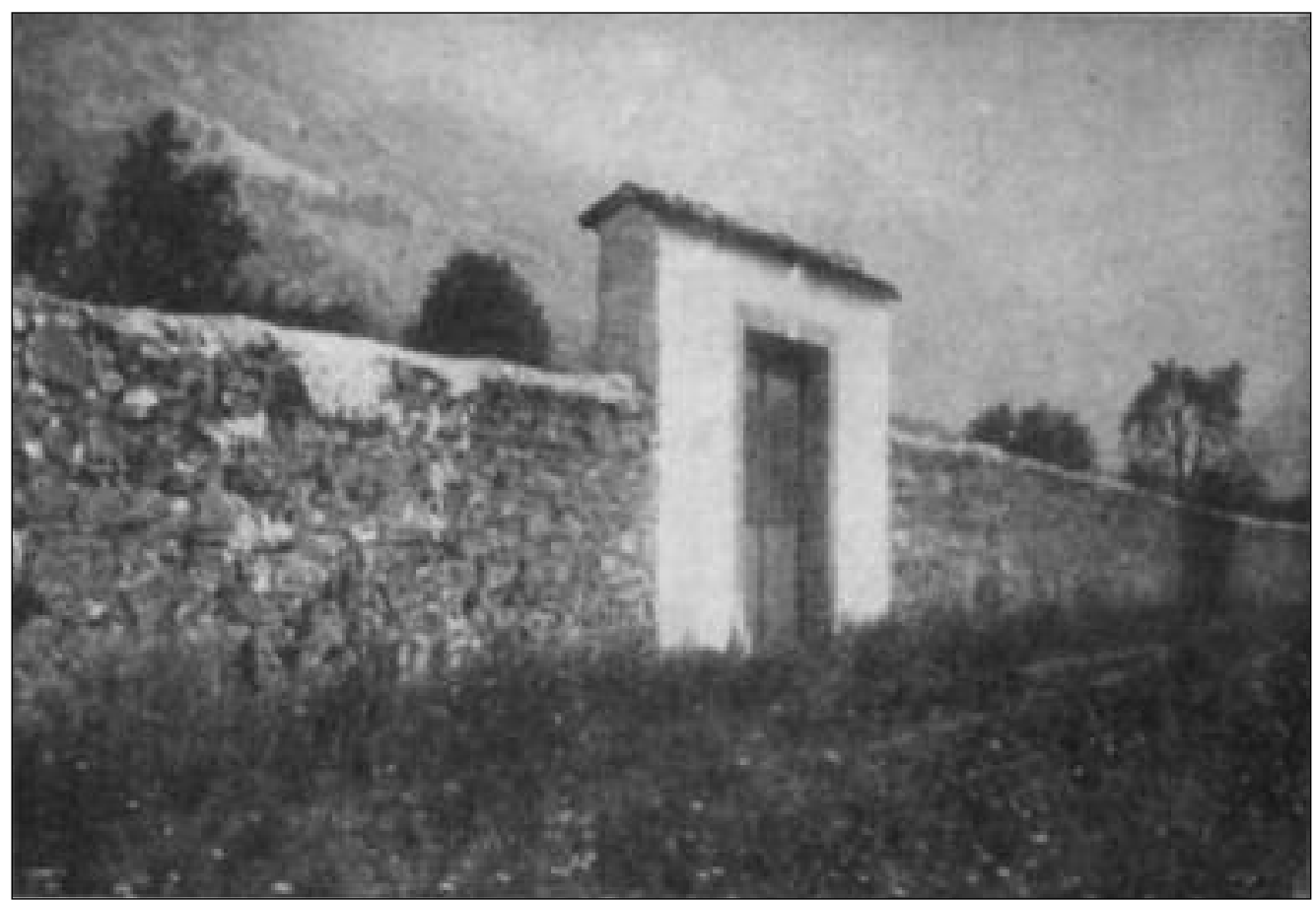

Slika 6: Jonkov vrtni zid v Bovcu so krasila mogočna vrata (Melik 1962, 357).

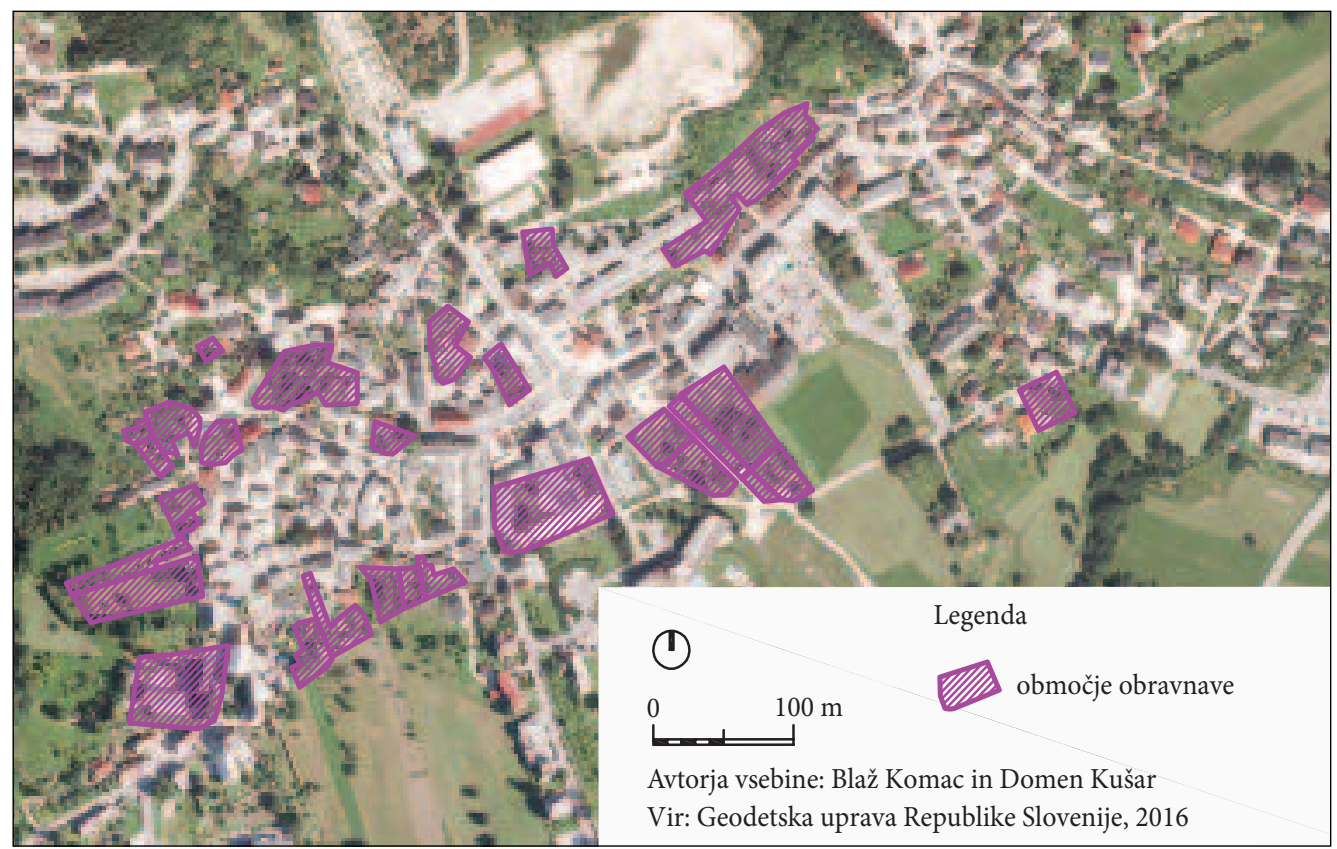

Slika 7: Predeli Bovca z večjim številom zidov in vrtov. 
kar je pokazal terenski ogled. Kamen je še vedno glavni gradbeni material, za vezivo pa služi malta, ki naredi zid vitkejši in trajnejši. Po besedah domačina (Pavlin 2017) naj bi v preteklosti v malto dajali jajčne beljake, da bi dosegali višjo trdnost. Za zaščito pred dežjem in zmrzaljo je vrhnji zaključek zaobljen. Nekateri novejši zidovi so zgrajeni iz armiranega betona, prav tako so armiranobetonski zaključki zidov in preklade pri prehodih. Enaka je tudi zaščita gornjega dela zidov, ki varuje pred vremenskimi vplivi in hkrati omogoča večjo varnost $\mathrm{v}$ primeru potresa. Poleg teh gradiv se v zidovih pojavljajo kovinske mreže in lesene late, ki zapolnjujejo polja med kamnitimi oziroma armiranobetonskimi stebriči in nizkim zidom pri tleh.

$\mathrm{Z}$ razvojem tehnologije in večjo dostopnostjo drugih gradbenih materialov, so prvotno funkcijo zidov prevzele različne vrste ograj. Te so ožje, cenejše, vendar tudi manj likovno sporočilne, zgodovinsko pričevalne in trajnostno naravnane, saj zahtevajo sprotno vzdrževanje. Njihova vedno pogostejša raba je posledica dejstva, da je področje zidov in ograj v Sloveniji zapostavljeno oziroma prepuščeno stihiji. Suhi zid, ograje, zidan zid in podobno spadajo po Uredbi o uvedbi in uporabi enotne klasifikacije vrst objektov in določitvi objektov državnega pomena (Uredba o uvedbi ... 2003) med »druge« gradbene inženirske objekte (CC-SI klasifikacijska številka 24205) in nimajo svoje razvrstitve. Uredba o razvrščanju objektov glede na zahtevnost gradnje (Uredba o razvrščanju ... 2013) uvrsti suhi zid med ograje (na zemljišču iste višine) ali podporne zidove (med zemljišči različnih višin). Višinske omejitve glede razvrstitve so do 0,5 m (enostavni objekti), 0,5-1,5 m (nezahtevni objekti), 1,5-25 m (manj zahtevni objekti), nad $25 \mathrm{~m}$ (zahtevni objekti). Zanimivo je, da ista Uredba (Uredba o razvrščanju ... 2013) žive meje in na primer lesenega plota sploh ne obravnava kot objekt. Prav tako Urbanistični terminološki slovar (Mihelič, Humar in Nikšič 2015) ne vsebuje terminov ograja in zid. Oba tudi nista navedena med urbano (ulično) opremo. Našteto odseva v prostorskih aktih lokalnih skupnosti, kjer se osredotočajo na zahteve za objekte, medtem ko je opredelitev zidov in ograj zapostavljena. Posledica je kaotično stanje na področju oblikovanja zidov in ograj, kjer si lahko vsak investitor zamisli svoj tip zidu ali ograje, ki v zadnjem času nadomeščajo zidove. Pri tem trpi celostni izgled urbanega in podeželskega okolja.

Proces zamenjave tradicionalnih kamnitih zidov se je v zadnjem stoletju odvijal tudi na Bovškem. Tako lahko danes na Bovškem zasledimo šest glavnih tipov »ločevalnih zidov« in ograj (sliki 8 in 9):

- Suhi zid (tip B1), je narejen iz kamenja in je verjetno najstarejša oblika zidov (Zupančič in Vinazza 2015; Deu 2015). Zahteva znanje in spretnost, saj je kamenje treba zložiti tako, da se ne poruši. Vzdrževanje takega zidu je enostavno, saj obsega le utrditev zrahljanih stikov. Gams (1991; 2003) ugotavlja, da so kamniti zidovi stranski rezultat prilagajanja zemljišč in torej predvsem oblika odlaganja kamenja, čeprav so obenem razmejevali parcele, varovali obdelana zemljišča pred živino in označevali individualno posest; njihova funkcija je zato bila kompleksna. Tudi Radinja (1987) suhim zidovom pripisuje multifunkcionalnost. Kamniti zidovi naj bi bili stranski rezultat vse večje prisotnosti in razpoložljivosti kamenja zaradi sprememb rabe zemljišč v zgodovinski dobi, pa tudi erozije. Hkrati pomenijo suhi zidovi tudi prostor biotske pestrosti, saj omogočajo mikro razmere za življenje različnim rastlinskim in živalskim vrstam (Bunce 2017).

- Poln zidan zid (tip B2) pomeni omejitev fizičnega dostopa in je hkrati tudi vizualna prepreka. Zid je iz lokalnega materiala, kot sta kamen, opeka. Za vezivo uporabijo malto boljše ali slabše kakovosti. Tak zid s svojo maso regulira mikropodnebje, saj se pod vplivom sonca podnevi segreje, ponoči pa oddaja toploto. Tak zid ima zelo dolgo življenjsko dobo, če ima na vrhu ustrezen zaključek - »streho«, ki ga varuje pred pronicanjem vode v notranjost. Življenjsko dobo lahko še podaljšamo z obojestranskim zaščitnim ometom.

- Lesena ograja (tip B3) je pogost omejitveni element na gozdnatih območjih in v alpskih pokrajinah. Z navpičnimi, v tla zabitimi koli in vodoravnimi letvami, ki so običajno iz lesa slabše kakovosti, doseže omejitev pristopa, glede na razmak med letvami pa je tudi vizualna prepreka. Namesto vodoravnih letev so lahko tudi navpične ali poševne, s čimer lahko izrazimo likovno sporočilen vzorec. Zaradi propadanja lesa, izpostavljenega vremenskih vplivom, taka ograja potrebuje sprotno vzdrževanje oziroma nadomeščanje propadajočih in uničenih elementov. 
- Kovinska (mrežna) ograja (tip B4) je ena najcenejših možnosti fizične ločitve dostopa na parcelo. Na Bovškem se je pojavila po koncu prve svetovne vojne, ko je bila med vojaškimi ostanki tudi žična mreža. Takšna ograja omejuje pristop, ne pa vizualne komunikacije. Namesto kovinske mreže se danes uporabljajo tudi mreža iz umetne mase, stekleni paneli in podobno.

- Pri kombinaciji »zidov« različnih tipov (tip B5) gre običajno za kombinacijo zidanega spodnjega dela ter kovinskega ali lesenega zgornjega dela. Na ta način se izkoristijo dobre lastnosti spodnjega, zidanega dela (trdnost, manjša občutljivost na vremenske in talne vplive) in lesenega ali kovinskega zgornjega dela (enostavnost in cenenost, prosojnost).

- Gosta zasaditev grmičevja in drugega zelenja (tip B6) je predvsem vizualna prepreka, čeprav je lahko tudi učinkovita fizična ovira, v odvisnosti od vrste zelenja in gostote zasaditve. Pregrada je še bolj učinkovita, če je kombinirana z mrežno ograjo. Tako imenovana "zelena ograja « je trajnostna in okolju prijazna rešitev ločevanja parcel. Ker gre za živ organizem, potrebuje stalno nego, predvsem v vzdrževanju želene oblike in zlasti višine.

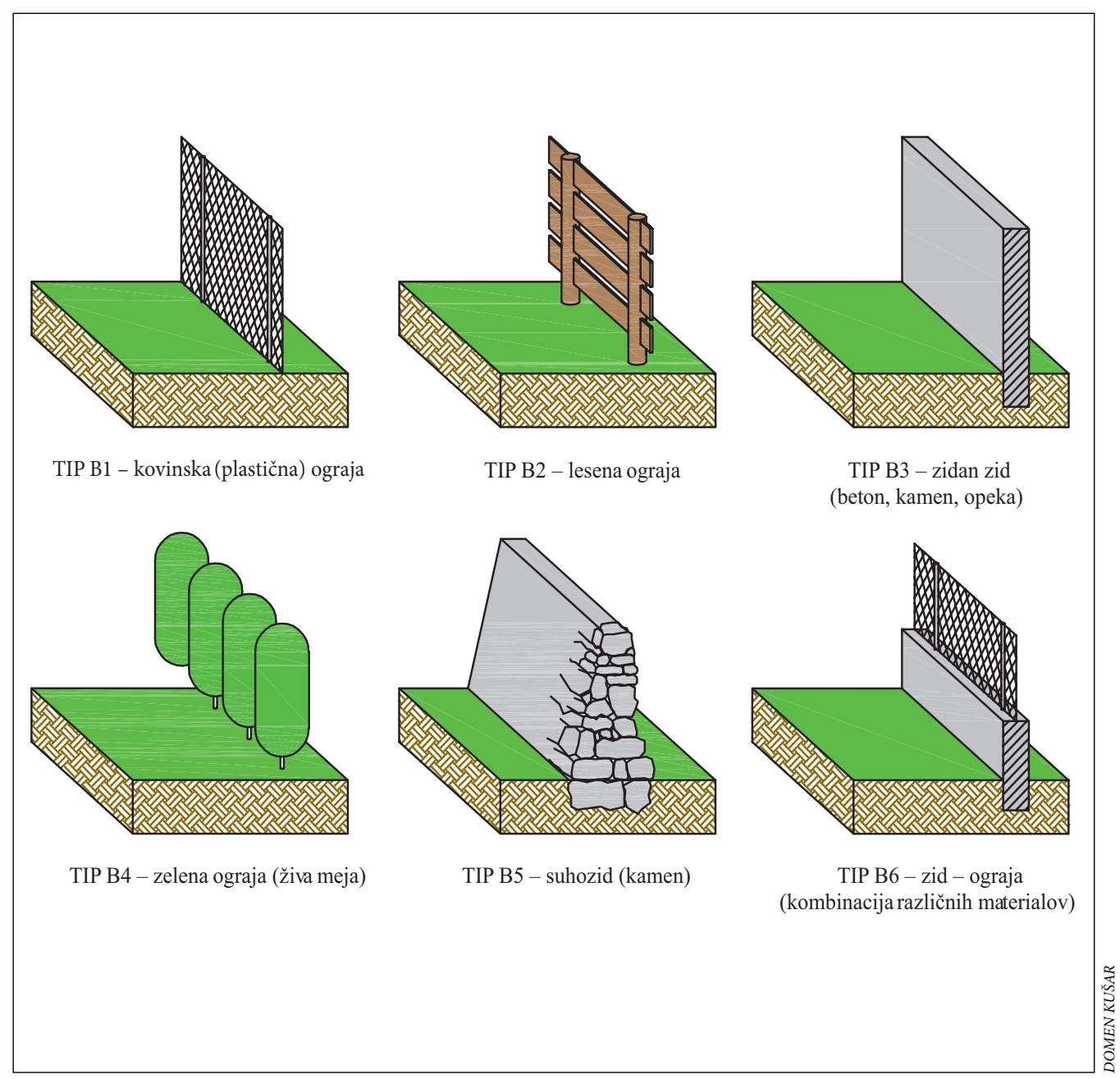

Slika 8: Tipi zidov in ograj. 


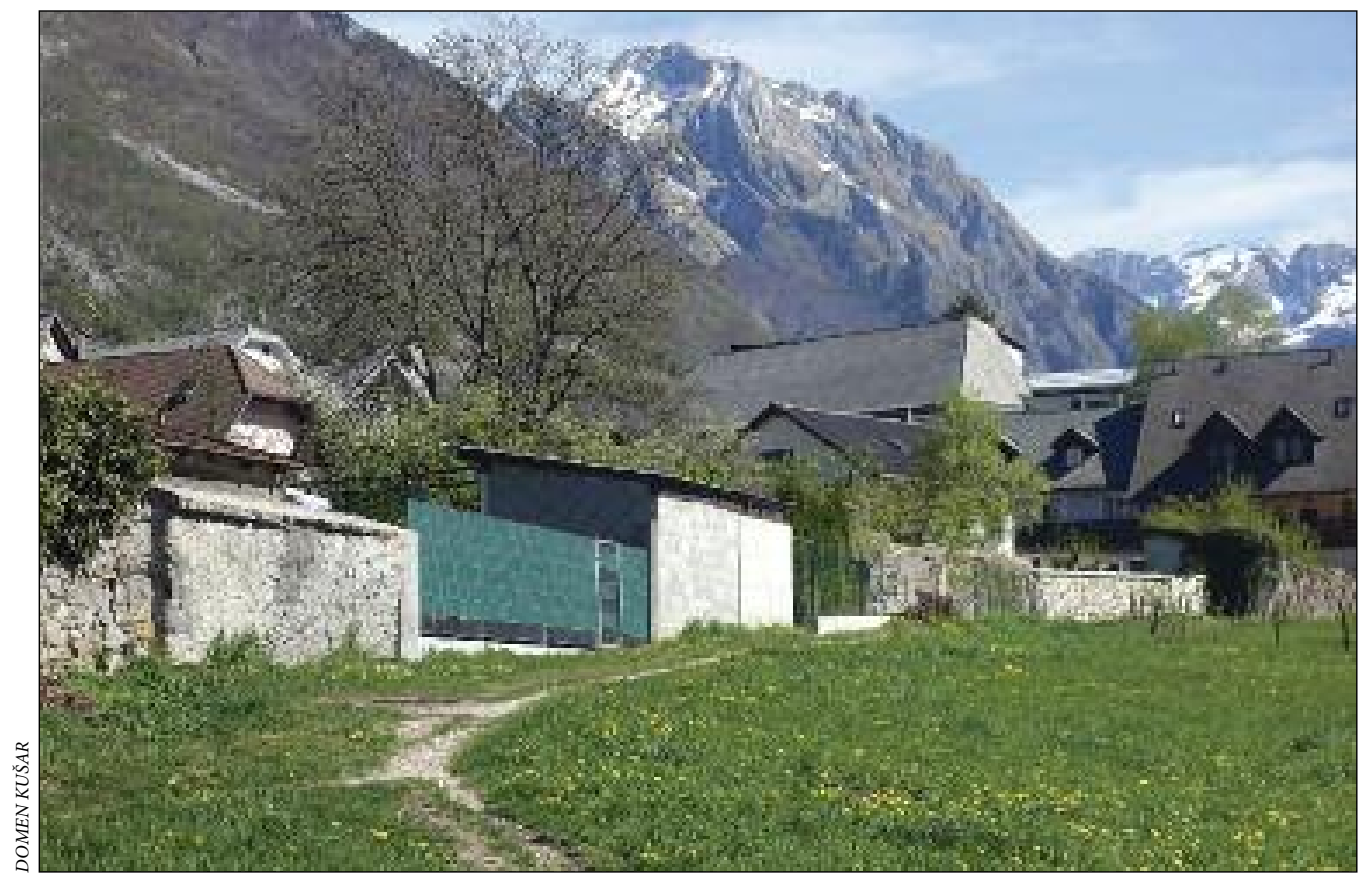

Slika 9: Starodavni vrtni zidovi na južni strani Bovca so deloma obnovljeni ali jih nadomeščajo ograje.

\section{Funkcija zidov in vrtov}

Prvotno so imeli zidovi verjetno predvsem dve funkciji: obrambno ali zaščitno in lastniško. Prva je obsegala varovanje prebivalcev, naselja, vrtov in pridelkov pred divjadjo in drugimi nepovabljenimi gosti, druga pa pomeni omejitev lastniških parcel. Slednje je značilno za zidove, ki obdajajo od domačij ločene zemljiške parcele, kar je značilno za južni del Bovca. Za obrobje naselja pa je pomembna še tretja funkcija, in sicer gospodarska. Vrtni zidovi so posredni kazalnik kulture vrtnarstva (slika 10), ki odseva sredozemski kulturni vpliv in je (bila) na Bovškem »... zelo v čislih in v vrtnih gredah gojijo obilo sadežev, ki so deležni zelo opazne skrbne nege ...«(Melik 1962, 359).

$\mathrm{Z}$ oblikovanjem in ohranjanjem vrtov v naseljih je neposredno povezano urbano vrtnarstvo. Gre za posebno - starodavno obliko kmetijske dejavnosti, ki pa znotraj obzidanih mest ni bila razširjena, saj je bil prostor znotraj obzidja predragocen za tovrstno dejavnost. Uveljavila se je v naseljih izven mestnih obzidij. Prvotno je bila namenjena preskrbi prebivalcev in meščanov z zelenjavo (Škerjanc 1970). To samoobrambno, lastniško in gospodarsko funkcijo vrtov v smislu samooskrbe prebivalstva s hrano oziroma menjave in prodaje viškov pridelane zelenjave, danes dopolnjujejo socialna in izobraževalna funkcija, funkcija ohranjanja kulturne dediščine ter turistična funkcija. V Londonu je tovrstna dejavnost danes zelo razvita: »Pridelovanje se odvija na komercialnih obratih v mestnem zelenem obroču, na majhnih zasebnih, javnih ali občinskih vrtovih in tudi na balkonih, terasah in strehah. Najbolj pogosti pridelki so sadje in zelenjava, meso, jajca, mleko, med in vino ...« (Vadnal in Alič 2008, 202). Za Bovec je pomembno, da so nekdanji vrtovi ostali obzidani tudi potem, ko je kmetija propadla ali je prenehala dejavnost vrtnarstva in se je funkcija parcele spremenila v parkovno ali stanovanjsko. Že Melik $(1962,338)$ ugotavlja, da se »... vidi težnja, da jih obdržijo v sklenjenem obsegu, pa tudi vrata da ohranijo v dobrem stanju ...«. 
V vrtnih zidovih torej vidimo pomemben element kulturne dediščine, saj nam pomagajo razložiti zasnovo naselja in kažejo na nekdanjo dejavnost, ki ima v sodobnem turističnem gospodarstvu lahko zopet pomembno vlogo. Sodobne turistične kmetije na primer kot višek gastronomske ponudbe ponujajo vrtnine »iz domačega vrta«.

Analiza rabe prostora v Bovcu (medmrežje 2) je pokazala, da je po katastru dejanska raba večine zemljišč »pozidano zemljišče«, ne glede na resnično stanje v naravi. Na območju "pozidanih « zemljišč so tudi zelene površine, kot so vrtovi, zelenice in sadovnjaki (Šmid Hribar 2016). Terenski ogled je pokazal, da domačini dobro skrbijo za vrtove. Gredice so obdelane, trava je pokošena, mejni zidovi urejeni. Vrtovi oziroma deli vrtov so namenjeni pridelavi zelenjave, drugod so pokriti s travo. Na njih rastejo sadna in tudi okrasna drevesa. Le manjši del vrtov zasedajo začasni objekti (barake) ali pa kot tlakovana površina služi za parkirišče. »Kmetijska zemljišča so zunaj območja naselja. Po namenski rabi večina parcel ustreza namenu »osrednjih območij centralnih dejavnosti«. Bistveno manj je »stanovanjskih površin, površin za oddih, rekreacijo in šport « (na primer igrišča) ter "površin za turizem « (hoteli).

Primer vključevanja zelenih zemljišč - vrtov v mestno tkivo je mestni predel Krakovo v Ljubljani. Krakovo je bilo poleg sosednjega Trnovega znano kot ljubljanski »solatendorf « - območje pridelave solate in ostale zelenjave, ki so jo nato prodajali na osrednji mestni tržnici. Trnovske vrtove so po drugi svetovni vojni večinoma pozidali z večstanovanjskimi bloki, medtem, ko je bilo Krakovo z značilnimi hiškami ob glavnih ulicah na ozkih in dolgih parcelah vrtov leta 1986 zaščiteno z mestnim odlokom. Veljavni Prostorski plan občine Ljubljana (medmrežje 3) ohranja tradicionalne gabarite in namembnost stavb na tem območju, prav tako pa je zaščitil tudi površine vrtov. Vrtovi so razdeljeni na ozke in dolge parcele, vendar te med seboj niso ločene z zidovi. Vrtovi so danes v treh sklenjenih območjih skupne površine $18.530 \mathrm{~m}^{2}$. Sklenjeno območje vrtov zaključujejo hiše oziroma kamnit ali opečni zid. Območje, ki je konec prejšnjega stoletja stagniralo, danes doživlja razcvet zaradi zelenih površin, miru in bližine ožjega središča mesta. Žal je raziskava o razvoju tega območja pokazala, da niti lastniki zemljišč in pre-

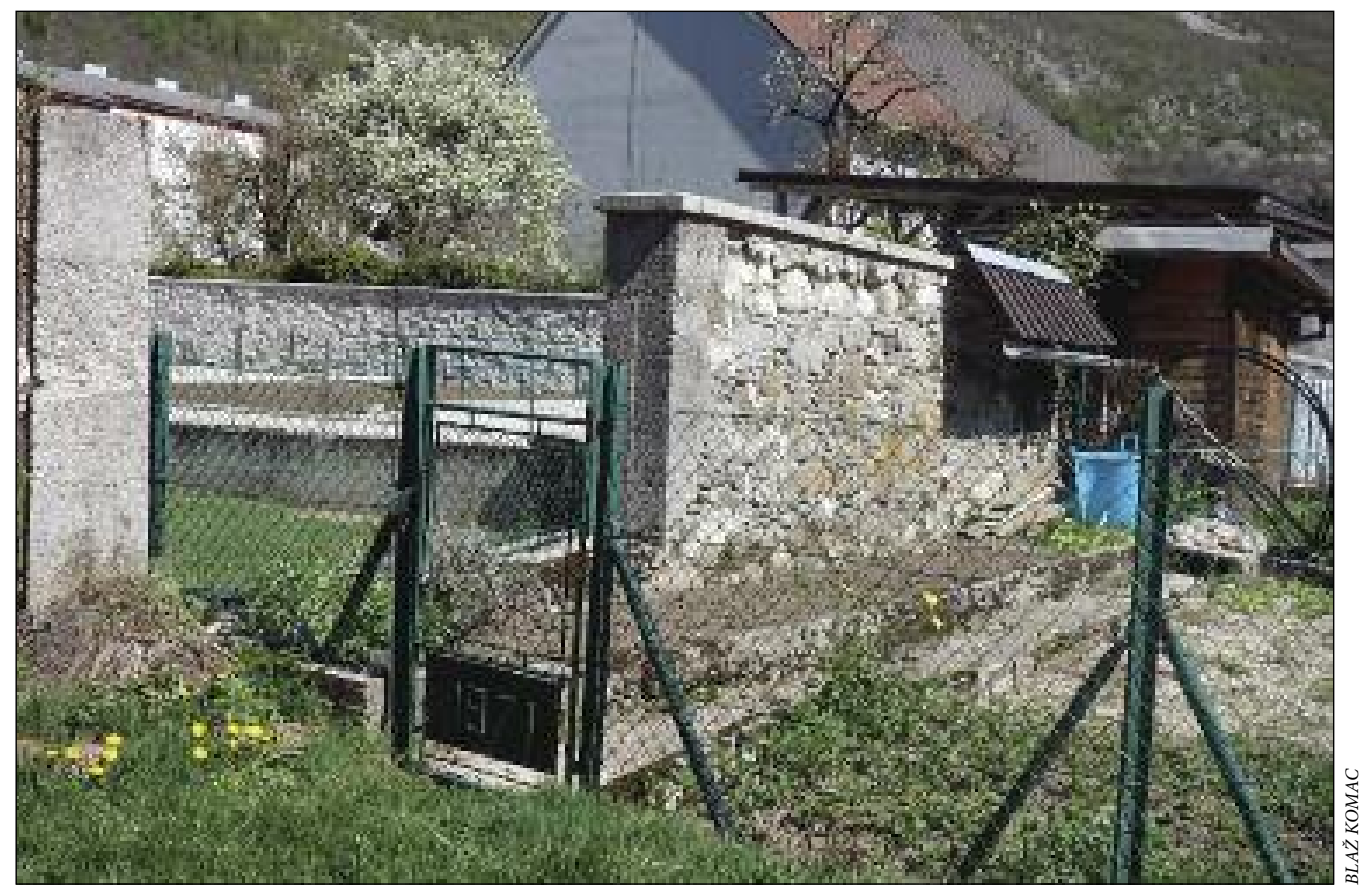

Slika 10: Primer obdelanih zemljišč med zidovi in ograjami. 
bivalci, niti mestna občina razen formalno izražene želje po obnovi in ohranjanju vrtov, nimajo avtentičnega interesa po ohranjanju vrtov in njihovem poslanstvu kot kmetijski ter tudi socialni, kulturni in izobraževalni dejavnosti (Vadnal s sodelavci 2011).

Primerjava parcel v Bovcu z rabo parcel v Krakovem kaže zanimive rezultate. Parcele v Krakovem so majhne. Po dejanski rabi so opredeljene kot "pozidana zemljišča «, in to ne glede na stanje v naravi. $\mathrm{Na}$ »pozidanih zemljiščih« trenutno raste zelenjava. Tu je položaj podoben kot v Bovcu. Bistvena razlika pa je v namenski rabi. Parcele v Krakovem so namenjene »stanovanjski površini, površini za vrtičke, parkom « in drugemu. Predvsem pa sklenjena območja krakovskih vrtov tvorijo parcele $\mathrm{z}$ namensko rabo "površin za vrtičke«.

Zidovi v Bovcu so imeli še eno pomembno funkcijo, to je prehodnost. Do izgradnje obvoznice leta 2006 so glavne prometne poti vodile z vzhoda (iz smeri Predela in Vršiča) proti zahodu (v smer Kobarida) in obratno skozi središče Bovca. Dostop do južno ležečih kmetijskih zemljišč pa je bil po več ozkih poteh. Med posameznimi parcelami Bovškega polja so namreč nastale poti, ki jih obdajajo zidovi (sopotje; slika 11), in vodijo čez travnike ali v središče naselja. Z zidom obdani vrtovi so značilni za robno območje naselja, kjer teče glavna cesta. Od tam se proti središču na gosto cepijo stranske ulice in poti. Nastanek zidov vzdolž poti se zdi nujna posledica dejstva, da so bila obdelovalna zemljišča v bližini vasi prepredena z mrežo poti. Ker je po poteh iz naselja hodila živina, ki so jo gnali na pašo, so zidovi bližje naselja običajno višji kot bolj oddaljeni. V Zabreznici in na Jezerskem so funkcijo zidov, ki so omejevali pot, po kateri je živina hodila na pašo, prevzela drevesa. Tovrsten pokrajinski element se imenuje »stagne«, na Jezerskem pa »ulice» (Badjura 1953; Šmid Hribar in Lisec 2011). Temeljna funkcija zidov je tako zaščita individualnih obdelanih zemljišč pred živino, ki hodi po javni, skupni poti. Zidovi na Bovškem so morali biti višji tudi zaradi prevlade drobnice, ki v nasprotju od goveda lahko prehaja čez nizke zidove. Zidovi so obenem jasno označevali mejo med zasebnimi zemljišči (Panjek 2015, 51), zato je razumljivo, da so povezani z večjimi kmetijami. Podobne poti, obzidane s suhim zidom, srečujemo danes po krasu in vzhodni jadranski obali.

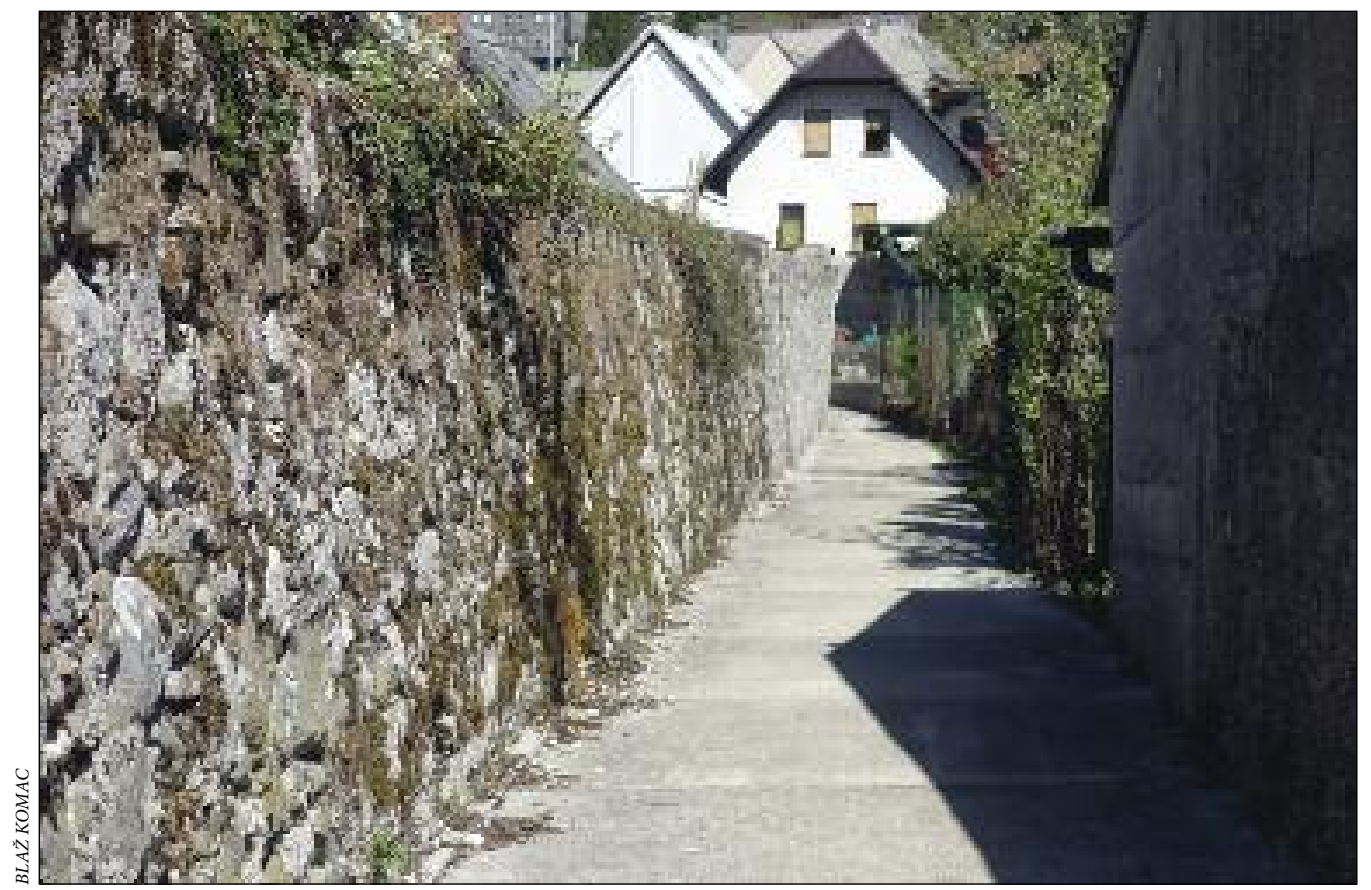

Slika 11: »Sopotje«. 


\section{Razprava}

Družbeno-gospodarske spremembe v Posočju pa tudi pogosti potresi in druge neprilike so v zadnjih desetletjih slabo vplivali na omenjene vrtne zidove. Nekatere so porušili zaradi zagotavljanja dostopnosti in gradnje širših poti. Drugi trpijo zanemarjanje zaradi opuščanja rabe vrtov. Ponekod so na robu naselja zrasle nove stavbe, ki posnemajo starodavno podobo v pomenu, da parcele ne obdaja zid, temveč ograja, lahko pa tudi obzidje, kot je primer pod nekdanjo bovško vojašnico. Ponekod so znotraj vrtov zrasli pomožni objekti, ki so lahko začasni ali pa zidani, redko pa celo stanovanjske stavbe.

Tovrstno tendenco kaže tudi Občinski prostorski načrt občine Bovec (2008), ki pravi, da je na teh območjih dovoljena gradnja eno- in dvostanovanjskih stavb, obzidani vrtovi pa niso posebej izvzeti kot prostorska enota oziroma jih prostorski izvedbeni pogoji, celo izrecno določajo kot območje pozidave (na primer območje BO40) ali javne infrastrukture - šole (BO37). Občina Bovec v svojih prostorskih razvojnih dokumentih teži k zgostitvam v prostorskem planu (27. člen). Faktor zazidanosti naj ne bi presegel 0,2, faktor izrabe pa ne 0,6. Velikost gradbene parcele se določi minimalno $125 \mathrm{~m}^{2} / \mathrm{os}$.

Stari del Bovca sodi v območje registrirane nepremične dediščine Bovec - Trško jedro, EŠD 10007 (Strokovne zasnove varstva ... 2008). To območje obsega stari del Bovca. Obravnavani zidovi so povečini v tem območju. To velja za zidove v središču kraja, na severnem in jugozahodnem delu, medtem ko so ohranjeni zidovi na jugovzhodnem delu kraja izven zaščitenega območja. Po besedah Andrejke Ščukovt (2017) z Zavoda za varstvo kulturne dediščine Nova Gorica (v nadaljevanju ZVKD Nova Gorica), ki skrbi za to območje, vedo za območja zidov v okolici Bovca, vendar žal nimajo dovolj sredstev in kadra za njihovo ovrednotenje. Za kakršne koli posege v območju registrirane nepremične dediščine je treba pridobiti kulturnovarstvene pogoje in nato soglasje. ZVKD Nova Gorica si prizadeva za ohranjevanje teh zidov z izdajo pogojev, ki zahtevajo ohranitev oziroma obnovo zidov po principu tehnike gradnje, ki je značilna zanje, in z uporabo lokalnega materiala. Terenski ogled je pokazal različno stopnjo ohranjenosti, obnov in novogradenj »zidov«. Ogled je pokazal, da so ljudje po koncu prve svetovne vojne za polnilo zidov začeli uporabljati vojaške ostanke - mrežno ter bodečo žico. Za vertikale pa so uporabljali železne traverze. Uporaba drugega dostopnega in cenejšega materiala se je nadaljevala tudi pozneje. Danes lahko vidimo različne, že omenjene tipe zidov oziroma ograj. Zdi se, da je osnovni namen teh zidov, to je ločevanje parcel, vrtov, ostal v zgodovinskem spominu domačinov, vendar se sedaj velikokrat raje pragmatično odločijo za cenejšo različico ograjo.

Občinski prostorski načrt občine Bovec (2008) neposredno ne varuje zidov in vrtov, vendar v 7. odstavku pravi, »... da dopustna gradnja ne sme ogrožati varstvenih območij in kulturnih vrednot /.../ in /.../ V kolikor se pojavi ta režim, je potrebno pridobiti predhodne pogoje in soglasja pristojne službe ...«. Ob tem je treba pripomniti, da urbano-podeželsko dediščino, ki jo obravnavamo v prispev$\mathrm{ku}$, niti na Bovškem niti v Sloveniji še ni bila prepoznana ter zato tudi ne ustrezno zaščitena in predstavljena. K tradicionalnim značilnostim poselitve tega in drugih območij namreč brez dvoma lahko prištevamo tudi omenjene zidove ter z njimi obdane vrtove na obrobju naselja in znotraj njega.

Ograjeni otoki zelenja (slika 5) kot ostanek starodavne kulturne dediščine (slika 12) pomenijo dodatno vrednost turistično usmerjenemu kraju, kot je Bovec, kjer je večina nastanitvenih zmogljivosti v manjših objektih ( 83 sob z 282 ležišči v hišah in 73 sob z 261 ležiščih v počitniških hišah) (medmrežje 4). Turistična ponudba občine temelji predvsem na aktivnem preživljanju prostega časa $\mathrm{z}$ »adrenalinskimi« športnimi dejavnostmi (vodni športi, zimski športi, kolesarjenje, pohodništvo) (medmrežje 4) in delno kulturno-zgodovinskimi (predstavitev ostankov prve svetovne vojne v zaprtih prostorih in na prostem). Te dejavnosti se običajno intenzivno odvijajo v enem delu dneva, drugi del pa je namenjen počitku, klepetu o preteklih doživljajih in pripravam na podvige naslednjih dni. Slednje se večinoma odvija v turističnih objektih in v restavracijah ter bifejih v centru mesta Bovec. Prav majhne ograjene zelene površine na robu naselja, ki pa so hkrati v bližini njegovega središča, nudijo ustrezen pol-javen oziroma zaseben prostor za ta drugi del aktivnega preživljanja prostega časa. S tem opravljajo socio- 


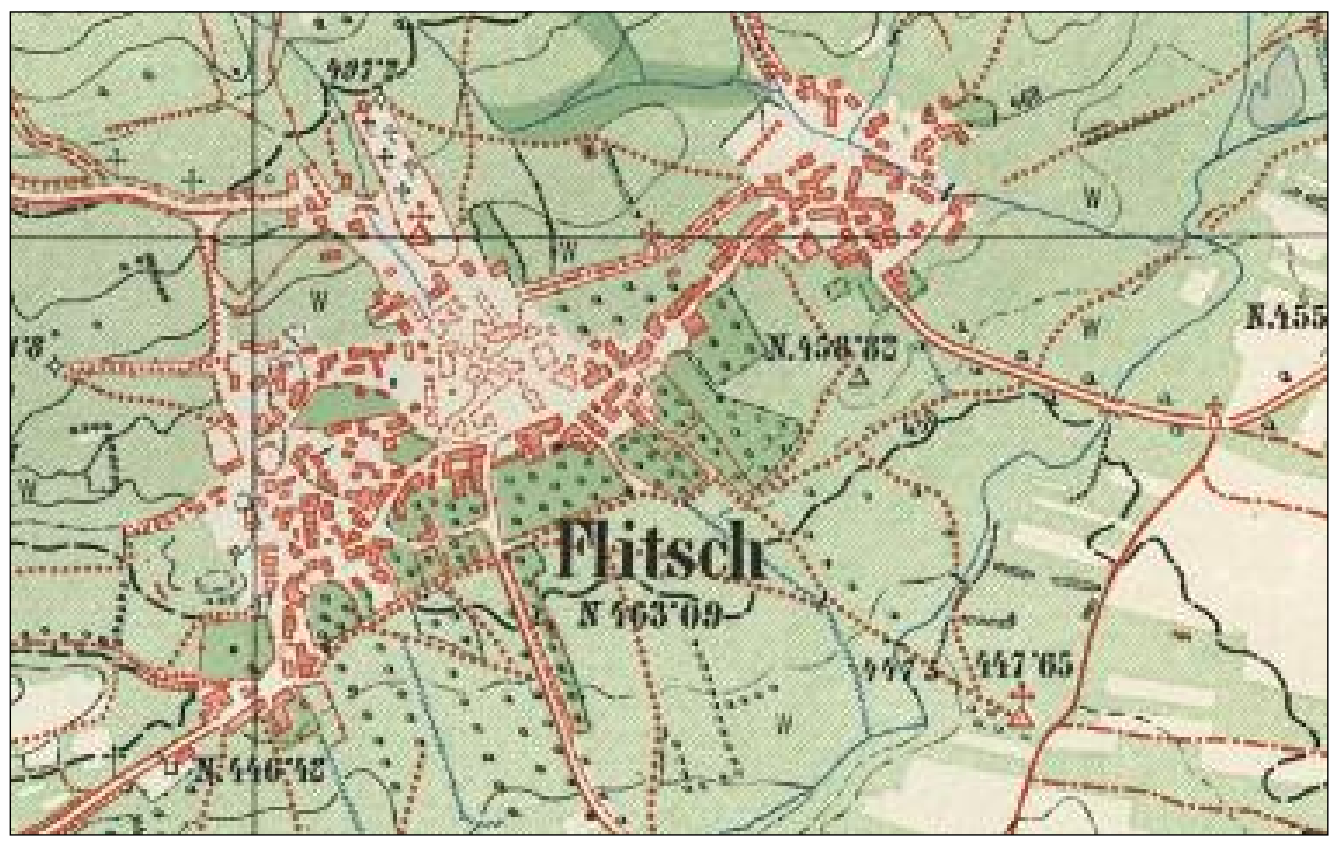

Slika 12: Primestni vrtovi in sadovnjaki ter zidovi, ki jih obdajajo, so bili pomemben del pokrajine za izdelovalca zemljevida iz leta 1906 (Festungs... 1906).

loško funkcijo grajenega zelenega okolja. Primarni namen ograjenih vrtov - pridelava zelenjave ter izobraževalni namen (spoznavanje zdravega načina pridelave hrane) je zaradi majhnega obsega lahko zgolj dopolnitev turistične ponudbe. Del tovrstne dediščine so na Bovškem že prepoznali. Dvorišče, narečno ime "gouf «, je že postalo prostor javnih kulturnih in drugih dogodkov ter temelj turistične dejavnosti (medmrežje 5).

Da pa bi zidovi in znotraj njih obdani vrtovi služili tudi kot arhaični ostanek preteklega časa ter postali del privlačne zgodbe kraja, bi jih morali lastniki in lokalna skupnost $\mathrm{v}$ širšem pomenu besede spoznati kot del svoje arhitekturno-urbanistične dediščine ter ustrezno z njimi tudi ravnati. Doseči slednje je zahtevna naloga, kar kažejo tudi rezultati anket o razmerju lastnikov in oblasti do revitalizacije Krakovega (Vadnal s sodelavci 2011).

\section{Sklep}

Hišno okolje in s tem povezano urbano-podeželsko kulturno pokrajino na Bovškem sestavljajo maloštevilni sestavni deli. Kajzelj (1999) jih našteje zgolj pet: »lašt, kašta, mir, plot in lesa « v prehodih. Ti pomembni deli bovške kulturne pokrajine kažejo skromnost ureditve obhišnega prostora in njegovo povezanost s prvobitno pokrajino, hkrati pa pričujejo o njegovi starodavnosti.

Nevarnost sedanjega časa je, da bi z nepremišljenimi posegi v prostor, pa četudi na temelju uresničevanja prostorskih načrtov, nepopravljivo razobličili to kulturno dediščino in s tem izgubili del svoje zgodovine, ki se razodeva $\mathrm{v}$ prostoru.

Primestni vrtni zidovi so zaradi svoje kulturno-zgodovinske vloge danes pomembna prvina kulturne pokrajine na Bovškem in tudi marsikje drugje v Posočju, kot smo videli pa tudi drugje v Sloveniji. $\mathrm{V}$ današnji dobi so posebej pomembni zaradi zagotavljanja otokov zelenja sredi pozidanih zemljišč in 
na prehodu naselja oziroma pozidanega območja v okolico, kar je lahko pomembna prvina sodobne turistične ponudbe.

Zahvala: Raziskava je nastala v okviru raziskovalnih programov Geografija Slovenije (P6-0101) in Trajnostno oblikovanje kvalitetnega bivalnega okolja (P5-0068).

\section{Viri in literatura}

Ažman Momirski, L., Kladnik, D. 2009: Terraced landscapes in Slovenia. Acta geographica Slovenica 49-1. DOI: https://doi.org/10.3986/AGS49101

Badjura, R. 1953: Ljudska geografija: terensko izrazoslovje. Ljubljana.

Bunce, B. 2017: The biodiversity of the dry-stone wall. Medmrežje: http://iale.uk/biodiversity-dry-stone-wall (18.9.2017).

Ciglič, R., Hrvatin, M., Komac, B., Perko, D. 2012: Karst as a criterion for defining areas less suitable for agriculture. Acta geographica Slovenica 52-1. DOI: https://doi.org/10.3986/AGS52103

Čok, B. 2014: Vzdrževanje in gradnja prostostoječih in podpornih kraških suhih zidov. Medmrežje: http://zvkds.si/sites/www.zvkds.si/files/uploads/files/publication/slo_zid.pdf (16.5.2015).

Deu, Ž. 2014: Gradimo za jutri; priročnik za trajnostno gradnjo s katalogom ponudnikov. Kobarid.

Festungs-Umgebungsplan der Sperre Flitsch 2. Österreichisches Staatsarchiv, Kriegsarchiv. Wien, 1906.

Franciscejski kataster za Primorsko, k.o. Bavšica (del Bovca), list A31. Arhiv Republike Slovenije. Ljubljana, 1809-1813.

Gams, I. 1987: Lokev - zemlja in ljudje. Lokev skozi čas. Ljubljana.

Gams, I. 1991: Sistemi prilagoditve primorskega dinarskega krasa na kmetijsko rabo tal. Geografski zbornik 31.

Gams, I. 2003: Kras v Sloveniji v prostoru in času. Ljubljana.

Gheorghiev, S., Shipeva, I. 1972: Koprivshtitsa. Sofija.

Hosner, E. 2017: Kamniti zidovi v Bovcu (osebni vir, 8. 4. 2017).

Hrvatin, M. 1988: Nekatere značilnosti zemljiške razdelitve in novejše spremembe izrabe tal na Bovškem. Pokrajina in ljudje na Bovškem. Ljubljana.

Juvanec, B. 2005: Kamen na kamen. Ljubljana.

Kajzelj, M. 1997: Bovška hiša. Ljubljana.

Kajzelj, M. 1999: Bovška hiša po velikonočnem potresu. Ljubljana.

Kladnik, D., Ciglič, R., Geršič, M., Komac, B., Perko, D., Zorn, M. 2016: Diversity of terraced landscapes in Slovenia. Annales, Series historia et sociologia 26-3. DOI: https://doi.org/10.19233/ASHS.2016.38

Klavora, F. 2003: Ampletium, Vliz, Plez, Flitsch, Belc: kdo dal podobo je Bovškemu: o zgodovini, življenju, cesti in naseljih na Bovškem. Tolmin.

Komac, B. 2001: The karst springs of the Kanin massif. Geografski zbornik 41.

Kravanja, V. 2017: Kamniti zidovi v Bovcu (osebni vir, 8. 4. 2017).

Kušar, D. 2003: Vpliv požarov na razvoj in podobo srednjeveških mest. Urbani izziv 14-2.

Lago, L. 1994: La memoria culturale del territorio. Le »casite«. Pietre e paesaggi dell'Istria centro-meridionale. Un censimento per la memoria storica. Fiume.

Medmrežje 1: Medmrežje: https://svetovalnica.zrc-sazu.si/topic/457/kako-imenujemo-kra\%C5\% Alke-kamnite-zidove (12.9.2017).

Medmrežje 2: http://www.e-prostor.gov.si/si/dostop_do_podatkov/vpogledi_v_podatke/mapa/javni_vpogled/ (26.7.2016).

Medmrežje 3: https://srv3dgis.ljubljana.si/Urbinfo/web/profile.aspx?id=Urbinfo@Ljubljana (20.3. 2017).

Medmrežje 4: http://pxweb.stat.si/pxweb/Dialog/Saveshow.asp (9.3.2017). 
Medmrežje 5: http://www.nesnovnadediscina.si/sites/default/files/lto_bovec_konferenca_cccvabilo_ in_program_sodelujoci_24_april_2014.pdf (9.3.2017).

Melik, A. 1950: Planine v Julijskih Alpah. Ljubljana.

Melik, A. 1962: Bovec in Bovško: regionalnogeografska študija. Geografski zbornik 7.

Mihelič, B., Humar, M., Nikšič, M. 2015: Urbanistični terminološki slovar. Ljubljana.

Moritsch, A. 1969: Das nahe Triester Hinterland. Zur wirtschaftlichen und sozialen Entwicklung vom Beginn des 19. Jahrhunderts bis zum Gegenwart. Wien.

Nicod, J. 1987: Amenagements agraires dans de petites depressions karstiques (en Provence et dans les Causes, et dans quelques régions de comparaison en Italie et Yougoslavie. Karst and Man: Proceedings of the International Symposium on Human Influence in Karst. Ljubljana.

Občinski prostorski načrt (OPN) Občine Bovec. Uradni list Republike Slovenije 119/2008. Ljubljana.

Pagnini, M. P. 1966: La casa rurale nel Carso triestino. Atti Museo Civico di storia naturale di Trieste 25-5.

Panjek, A. 2015: Kulturna krajina in okolje Krasa. Medmrežje: http://www.hippocampus.si/ISBN/ 978-961-6963-35-0.pdf (16. 5. 2016).

Pavlin, Z. 2017: Kamniti zidovi v Bovcu (osebni vir, 8. 4. 2017).

Postava sa volo ogna na kmetih. Arhiv Republike Slovenije. Ljubljana, 28. januar 1795.

Radinja, D. 1987: Modern land improvement in Slovene Dinaric Karst. Removal of rock on the continental side and spreading of clay on the littoral side of Karst. Karst and Man: Proceedings of the International Symposium on Human Influence in Karst. Ljubljana.

Razpotnik Visković, N., Komac, B. 2018: Agriculture in modern landscapes: A factor hindering or facilitating development? Acta geographica Slovenica 58-1. DOI: https://doi.org/10.3986/AGS.5170

Shaw, T. R. 2000: Foreign Travellers in the Slovene Karst 1537-1900. Ljubljana.

Strokovne zasnove varstva kulturne dediščine za območje občine Bovec. ZVKD Slovenije, Območna enota Nova gorica. 2008. Medmrežje: http://giskd2s.situla.org/evrdd/SZ/eVRD_SZ_Bovec_2008_ 02_00.pdf (16.5.2016).

Ščukovt, A. 2017: Varstveni status zidov v Bovcu (osebni vir, 10. 4. 2017).

Škerjanc, N. 1970: Mestna četrt Krakovo v Ljubljani. Geografski vestnik 42.

Šmid Hribar, M. 2016: Varovanje in trajnostni razvoj kulturne pokrajine na primeru Ljubljanskega barja. Georitem 27. Ljubljana.

Šmid Hribar, M. Lisec, A. 2011: Protecting trees through an inventory and typology: heritage trees in the Karavanke mountains, Slovenia. Acta geographica Slovenica 51-1. DOI: https://doi.org/10.3986/ AGS51108

Tiran, J. 2016: Measuring urban quality of life: case study of Ljubljana. Acta geographica Slovenica 56-1. DOI: https://doi.org/10.3986/ags.828

Uredba o razvrščanju objektov glede na zahtevnost gradnje. Uradni list Republike Slovenije 18/2013. Ljubljana.

Uredba o uvedbi in uporabi enotne klasifikacije vrst objektov in določitvi objektov državnega pomena. Uradni list Republike Slovenije 33/2003. Ljubljana

Vadnal, K., Alič, V. 2008: Mestno kmetijstvo - oblike in izkušnje. Acta agriculturae Slovenica 91-1.

Vadnal, K., Jakše, M., Alič, V., Jereb-Bolka, D. 2011: Participativno raziskovanje večnamenskosti Krakovskih vrtov kot podlage za ohranitev zaščitene mestne kmetijske kulturne dediščine. Acta agriculturae Slovenica 97-1.

Zupančič, D., Vinazza, M. 2015: Suhozidna gradnja v prazgodovini na Krasu. Kronika 63-3. 


\section{Summary: Traces of rural heritage in urban landscapes: walled yards in the Bovec area}

(translated by the authors)

This article discusses stone walls, a feature commonly found in Mediterranean and other cultural areas. Their origins are connected with clearing agricultural land to facilitate farming, to semi-permanently delimit parcels, and to keep livestock out. This landscape element is presented using the case of Bovec, where walls enclose the local yards and farms. They are an important cultural landscape element and, because local materials were used to build them and they are related to the origin of settlement, they are classified under cultural heritage. In addition, they are an interesting element of the settlement's spatial organization, which points to their considerable age and the settlement's connection with the surrounding areas.

In Bovec and its environs, these structures are now typically part of the settlement and its surroundings. The stone walls enclose the gardens and yards and then continue into the adjacent land. A comparison of old cadastral maps, written and oral sources, and fieldwork revealed an old building tradition, which took into account the natural conditions and the requirements of the inhabitants. At the same time, they are an example of rural elements in the urban environment. The results showed that this is a frequently overlooked element of cultural heritage, which also has tourism potential.

To this end, the types of walls and their current state and purpose were examined. The walls appear inside the settlement between houses as well as on its edges. The largest number of them and the bestpreserved ones can be found on the southern side of Bovec, where the settlement extends into a basin. The original material used for the walls was stone obtained from the immediate vicinity. They were built using the dry-stone wall technique. Later on, rock for the walls was also quarried on the slopes of Mount Rombon. After the First World War, locals used remnants of military infrastructure as building material. The structure of the walls then began to change, with military welded wire mesh and barbed wire being used instead of stone. On the other hand, the constant renovation and maintenance of the walls, which deteriorate due to age, neglect, and damage caused during the First World War as well as by the 1976, 1998, and 2004 earthquakes, is reflected in today's typology. Only a few of them were built as dry-stone walls. Their structure and design also mirror the progress made in construction techniques and the greater availability of various building materials in recent decades, which was identified during a site inspection. Stone remains the main building material and mortar is used as the binding agent, making the walls thinner and more durable. A rounded top was used to protect the walls from rain and frost. Among the more recent walls, some are built from reinforced concrete, which can also be found in the wall finishes and the lintels above the entryways. The upper parts are also made of this material to protect the walls from weather and provide greater safety during earthquakes. In addition to these materials, metal mesh and wooden slats can also be found in these walls; they fill in the spaces between stone or reinforced-concrete pillars and a low wall near the ground. Hence, today one can no longer speak of walls in the narrow sense of the word, but in a broader sense that also encompasses other types of spatial delimitation. Based on the material used, six basic types of "walls« between yards were identified (Figure 8):

- Dry walls (Type B1) made of rocks are probably the oldest type of wall. According to Gams (1991; 2003), stone walls are a side product of adapting the land and hence primarily a method of depositing rocks, even though they were also used to delimit parcels, protect tilled land from livestock, and demarcate an individual property; they thus had a complex function.

- Solid walls (Type B2) restrict physical access and at the same time create a visual barrier. The wall is made of local material, such as stone and brick. If it has a suitable finish at the top (a »roof «) to protect it from water seeping inside, it can have an extremely long service life.

- Wooden fencing (Type B3) is a frequent delimitating element in wooded areas and alpine landscapes. With their vertical stakes driven into the ground and horizontal rails, usually made of poorer-quality wood, these fences restrict access, and depending on the gaps between the rails they also form a visual barrier. 
- Metal (mesh) fencing (Type B4) is one of the cheapest ways of physically restricting access to a parcel. Such a fence limits only the access and not the visual communication. Plastic mesh, glass panels, and other similar materials are also used instead of metal mesh.

- A combination of various types of »walls« (Type B5) usually includes a combination of a lower masonry part and an upper metal or wooden part. This makes it possible to make good use of the qualities of the lower masonry part (sturdiness and less sensitivity to weather and ground effects) and the upper part made of wood or metal.

- Thickly planted shrubs and other greenery (Type B6) primarily form a visual barrier, but they can also serve as an effective physical barrier, depending on the type of greenery used and its thickness.

Some of these walls can be found in the old market town area of Bovec, which has been declared part of Slovenian settlement cultural heritage. Unfortunately, the Nova Gorica Cultural Heritage Protection Institute, which is responsible for this area, does not have sufficient funds and staff for suitable evaluation and protection. However, the institute is involved in procedures for obtaining permits to develop the settlement heritage protection area by establishing cultural-protection conditions and issuing approvals. A site inspection revealed that locals mostly maintain these walls, especially on the southern edge of the town.

Walls enclose the town's green areas, especially vegetable gardens and yards. A mix of green areas and urban landscape provides a higher quality of life for the people. However, it has been established that the current spatial use and the spatial plans of the Municipality of Bovec show little consideration for the importance of walls as high-quality spatial elements. Even green areas are not protected against development, in contrast to, for example, the similar case of the Krakovo neighborhood in Ljubljana. The purpose of this presentation is to draw attention to this type of cultural heritage, which is often overlooked, and to encourage spatial planners to take into account and preserve these assets in the towns' spatial plans. At the same time, these types of spatial elements improve the quality of the living environment and provide development potential, especially in tourism. 